\title{
Growth and Yield Performance of Garlic (Allium sativum L.) Varieties to Application of Vermicompost at Koga Irrigation Site, Northwestern Ethiopia
}

\author{
Bewuket Gashaw* \\ Department of Horticulture, Wolkite University, P.O.Box 07 Wolkite, Ethiopia \\ Professor Kebede Woldetsadik \\ College of Agriculture and Environmental Sciences, Haramaya University, P.O.Box 138 Dire Dawa, Ethiopia \\ Ketema Belete $(\mathrm{PhD})$ \\ College of Agriculture and Environmental Sciences, Haramaya University, P.O.Box 138 Dire Dawa, Ethiopia
}

\begin{abstract}
Garlic (Allium sativum L.) is an important cash and spice crop produced for home consumption and as a source of income to many smallholder farmers in many parts of the Ethiopia. Field experiment was conducted at Adet Agricultural Research Center, Koga irrigation trial site in 2015/2016 cropping season. Three garlic varieties (Bishoftu Nech, Tsedey and a local cultivar) and three levels of vermicompost fertilizer $\left(0,2500,5000 \mathrm{~kg} \mathrm{ha}^{-1}\right)$ were tested in Randomized Complete Block Design (RCBD) with three replications. Bishoftu Nech variety gave significantly the highest total and marketable bulb yield 8.50 and 8.10 ton ha ${ }^{-1}$, respectively, that exhibited 24 and $57 \%$ advantages over Tseday and the local cultivar, respectively. The highest values of mean bulb weight (37.85 $\mathrm{g})$, mean clove number (9.92), mean clove weight (5.65 g), total fresh biomass yield (47.82 g/plant) and bulb dry matter $(19.62 \%)$ was recorded from Bishoftu Nech variety with application of $5000 \mathrm{~kg} \mathrm{ha}^{-1}$ vermicompost. Therefore, based on the current study, it can be concluded that producers in the study area could use Bishoftu Nech variety using $5000 \mathrm{~kg} \mathrm{ha}^{-1}$ vermicompost for optimum garlic production.
\end{abstract}

Keywords: Variety, vermicompost, yield, optimum garlic production, maximum economic benefit

DOI: $10.7176 / \mathrm{JBAH} / 10-23-01$

Publication date: December $31^{\text {st }} 2020$

\section{Introduction}

Garlic (Allium sativum L.) is one of the main Allium vegetable crops known worldwide with respect to its production and economic value. It is native to southern Europe and western Asia (Etoh and Simon, 2002). It is used for seasoning in many foods worldwide; without garlic many of our popular dishes would lack the flavor and character that make them favourites. In Ethiopia, the total area under garlic productionin 2013/2014 reached 16,412 ha and the production is about 15,909 ton of bulbs respectively (CSA, 2014). Because of an increasing cost of inorganic fertilizers and shifts in policies with respect to subsidize fertilizer costs, the use of inorganic fertilizers by small scale producers is becoming unaffordable (Tadila, 2011). Crop yield cannot be maintained through the use of inorganic fertilizers alone under continuous cultivation. Hence, Integration of organic and inorganic fertilizers is being advocated as one of the strategic solutions to maintain soil fertility (Ahmad et al., 1996; Khaliq et al., 2004).

Among the many organic fertilizers, vermicompost is a potential organic nutrient source which provides additional plant nutrients that are not found in inorganic fertilizers (Kale et al., 1992). Vermicomposts are finely divided peat like materials with high porosity, aeration, drainage and water-holding capacity and usually contain most nutrients in available forms such as nitrates, phosphates, exchangeable calcium and soluble potassium (Atiyeh et al., 2002; Arancon et al., 2004). They also enhance uptake of nutrients by plants (Nagavallemma et al., 2004). Palm et al. (1997) reported that the uptake of nitrogen, phosphorus, potassium, zinc, manganese, copper and iron were increased significantly by crops when $50 \%$ of organic fertilizers in combination with $50 \%$ inorganic fertilizers were applied.

In Ethiopia, information on the vermicompost fertilizers on garlic growth, yield and yield components is limited. Vermicomposting had been an easy technology, environmentally friendly process used to treat organic waste. This organic fertilizer was being therefore increasingly considered in agriculture and horticulture as a promising alternative to chemical fertilizers. However, the effects of vermicompost on garlic were not yet fully understood in Ethiopian condition Thus, keeping in view of creating sustainable soil health condition for sustainable agriculture in one side and considering garlic as one of the potential vegetable crop for consumption as well as for market in the other side, it is imperative to increase its productivity along with desirable attributes through production management practices and application of other sources of nutrients beyond inorganic fertilizers like urea $(46 \% \mathrm{~N})$ and DAP $\left(18 \% \mathrm{~N}\right.$ and $\left.46 \% \mathrm{P}_{2} \mathrm{O}_{5}\right)$. Therefore, this research was conducted to assess the growth 
and yield performance of garlic varieties to the application of vermicompost fertilizer.

\section{Materials and Methods}

\subsection{Description of the Study Area}

The experiment was conducted at Adet Agriculture Research Centre, Koga Irrigation Trial Site which is found in Mecha District, West Gojam Administration Zone of Amhara National Regional State. The site is situated at $10^{\circ} 30^{\prime} 0{ }^{\prime \prime} \mathrm{N}$ latitude and $37^{\circ} 30^{\prime} 02.4^{\prime \prime} \mathrm{E}$ longitude at an altitude of 1960 masl. It is about $42 \mathrm{~km}$ southwest of Bahir Dar and $535 \mathrm{~km}$ northwest of Addis Ababa. The mean annual rainfall for the area is $1500 \mathrm{~mm}$ and the average temperature is $16-20{ }^{\circ} \mathrm{C}$. The soil texture of the experimental site was clay (clay $53 \%$, silt $12 \%$ and sand $35 \%$ ) and $\mathrm{pH}$ was 5.0.

\subsection{Description of the Experimental Material}

Two garlic varieties named Tsedey and Bishoftu Nech which were released by one of the pioneer agricultural research centre in Ethiopia called DebreZeit Agricultural Research Centre; and one local cultivar were used. The two garlic varieties are among the most and common commercial garlic varieties in Ethiopia. The vermicompost was used as organic fertilizer supplying all elements required by the plant.

\subsection{Treatments and Experimental Design}

The treatments consisted of three garlic varieties (Tsedey, Bishoftu and local cultivar) and three levels of vermicompost $\left(0,2500,5000 \mathrm{~kg} \mathrm{ha}^{-1}\right)$. The experiment was laid out in a Randomized Complete Block Design (RCBD) and replicated three times.

\subsection{Experimental Procedures}

The experimental field was ploughed three times and well harrowed. Soil clods were broken by human labour and experimental plots were laid out on fine seedbed. Medium-sized cloves from bulbs stored for about 5 months with dry tops attached were prepared for planting. Vermicompost was applied one month before planting by cutting open furrows and incorporating it into planting rows at the depth of about $10-15 \mathrm{~cm}$. At planting time, cloves were separated from the bulbs, sorted and graded according to size category. Large to medium size (1.5 to $2.5 \mathrm{~g}$ ) cloves (Fikreyohannes, 2005) were used for planting. Garlic varieties were planted during 2015/2016 cropping season at Adet Agricultural Research Center; Koga Irrigation Trial Site which is found in West Gojjam Zone of the Amhara Region. Weed control was done by hoeing and shallow earthing up. Other crop management practices were done as required after plant emergence. Harvesting was done when $70 \%$ of the leaves senesced. The harvested bulbs were windrowed in the field and sun-dried for ten days, folding the leaves over the bulbs to protect them from sunburn. After a week of curing, tops and roots were trimmed.

\subsection{Data Collection and Measurement}

Data on phenological, growth and yield related agronomic parameters of garlic varieties were recorded starting from planting to harvesting. Phonological parameter: days to emergence, days to bulb maturity; growth parameters: plant height, number of leaves per plant, leaf area index; yield parameters: mean bulb weight, mean clove number per bulb, mean clove weight, total fresh biomass yield (g/plant), total number of bulbs, marketable bulb yield ( $\mathrm{t}$ $\mathrm{ha}^{-1}$ ), unmarketable bulb yield (ton ha ${ }^{-1}$ ), total bulb yield (ton ha ${ }^{-1}$ ), bulb dry matter percent, harvest Index was recorded.

\subsection{Data Analysis}

Data were subjected to analysis of variance (ANOVA) using GenStat $15^{\text {th }}$ edition, version 15.1. Whenever treatment differences were found to be significant, means were separated using the Least Significant Difference (LSD) test at 5\% level of significance. Correlation analysis was performed to detect the linear relationships among yield, and growth attributes. The economic analysis was also done according to CIMMYT (1988) using the concept of partial budget.

\section{Results and Discussion}

\subsection{Days to Emergence}

The main effect of variety and vermicompost significantly $(\mathrm{P}<0.001)$ influenced days to emergence. However, the interaction effect of variety and levels of vermicompost fertilizer did not significantly affected days to emergence. Bishoftu Nech emerged 2 days earlier than the local cultivar and 3 days earlier than Tsedey, whereas, Tsedey emerged 1 day later than the local cultivar (Table 1).

Increasing application of vermicompost decreased number of days required to emerge garlic sprouts above the soil by 5-9 days. This result is in agreement with finding of Alemu (2016) who reported that with the increase in the rate of vermicompost application, the number of days required by the garlic sprouts to emerge above the soil 
surface was decreased. Application of $5000 \mathrm{~kg} \mathrm{ha}^{-1}$ vermicompost hastened the emergence of garlic sprouts from the soil by about 9 days as compared to the control. Similarly, application of $2500 \mathrm{~kg} \mathrm{ha}^{-1}$ vermicompost accelerated sprouting of garlic cloves by about 9 and 5 days as compared to the control. The accelerated duration of emergence might have attributed to the influence of available nutrients of vermicompost on root initiation and development which might have led to early shoot emergence. Using vermicompost as a substrate produced an earlier shoot emergence and earlier start of bulbification which corresponds to increase in the total soluble carbohydrates and a subsequent modification in the non-structural carbohydrate distribution patterns, and hence a modification in the pattern of fructan (scorodose) metabolism (Argüello et al.,2006). Table 1. Main effects of garlic varieties and vermicompost on days to emergence

\begin{tabular}{ll}
\hline Treatments & Days to emergence \\
\hline Varieties & $18^{\mathrm{b}}$ \\
Local & $19^{\mathrm{a}}$ \\
Tsedey & $16^{\mathrm{c}}$ \\
Bishoftu Nech & 0.959 \\
LSD (5\%) & $24^{\mathrm{a}}$ \\
\hline Rate of vermicompost & $21^{\mathrm{b}}$ \\
No fertilizer (control) & $15^{\mathrm{c}}$ \\
\hline $2500 \mathrm{~kg} \mathrm{ha}^{-1}$ & 1.27 \\
$5000 \mathrm{~kg} \mathrm{ha}^{-1}$ & 8.51 \\
\hline LSD (5\%) & $8.5 \%$ \\
CV $(\%)$ &
\end{tabular}

*Means followed by the same letter within a column are not significantly different at $5 \%$ level of significance, $\mathrm{LSD}=$ Least significant differences; $\mathrm{CV}=$ coefficient of variation

\subsection{Days to Maturity}

Analysis of the experiment showed that days to maturity was significantly influenced by the main effects of varieties and vermicompost as well as by their interaction effect at $\mathrm{P}<0.001$ level of significance. As in indicated in Table 2 below, Bishoftu Nech variety with the application of $2500 \mathrm{~kg} \mathrm{ha}^{-1}$ showed longest days to bulb maturity. However, the two varieties namely the local and Tsedey variety showed longest days to maturity with the application of $5000 \mathrm{~kg} \mathrm{ha}^{-1}$. This difference in days to bulb maturity might be due to the genetic variability of the varieties. The interaction effect variety and vermicompost also indicated that all garlic cultivars matured earlier in the unfertilized plots. This result is in agreement with that of the findings of Tadila (2011) who reported prolonged maturity on garlic in response to combined application of $\mathrm{N}$ and manure.

Table 2. Interaction effects of garlic varieties and vermicompost on days to bulb maturity

\begin{tabular}{llll}
\hline \multirow{3}{*}{ Varieties } & \multicolumn{3}{c}{ Rate of vermicompost } \\
\cline { 2 - 4 } & No fertilizer (control) & $2500 \mathrm{~kg} \mathrm{ha}^{-1}$ & $5000 \mathrm{~kg} \mathrm{ha}^{-1}$ \\
\hline Bishoftu Nech & $133.61^{\text {cde }}$ & $146.12^{\mathrm{a}}$ & $133.74^{\text {cd }}$ \\
Local & $128.00^{\mathrm{g}}$ & $130.00^{\mathrm{d}}$ & $134.64^{\mathrm{c}}$ \\
Tsedey & $133.00^{\mathrm{e}}$ & $136.21^{\mathrm{ib}}$ & $137.00^{\mathrm{b}}$ \\
\hline LSD $(5 \%)$ & 1.224 & & \\
CV $(\%)$ & 5.9 & & \\
\hline
\end{tabular}

* Means followed by the same letter within a column are not significantly different at $5 \%$ level of significance, $\mathrm{LSD}=$ Least significant differences; $\mathrm{CV}=$ coefficient of variation

\subsection{Plant Height}

Varieties and vermicompost significantly influenced Plant height at $1 \%$ level of significance. The highest $(28.15$ $\mathrm{cm}$ ) and lowest $(17.81 \mathrm{~cm})$ were recorded in local and Bishoftu Nech varieties with treatment application of 5000 $\mathrm{kg} \mathrm{ha}^{-1}$ and nil, respectively (Table 3). The analysis also revealed that all varieties showed taller heights with application of $5000 \mathrm{~kg} \mathrm{ha}^{-1}$ vermicompost than other treatments. The increase in plant height due to increased rate of vermicompost could be attributed to the fact that vermicompost contains a good range of some very essential macro and micronutrients other than $\mathrm{N}$ and $\mathrm{P}$ which are required for healthy plant growth (Surindra, 2009). The difference in plant height between the varieties could be ascribed to the genotypic variability. 
Table 3. Interaction effects of garlic varieties and vermicompost on plant height $(\mathrm{cm})$

\begin{tabular}{llll}
\hline & \multicolumn{3}{c}{ Rate of vermicompost } \\
\cline { 2 - 4 } Varieties & No fertilizer (control) & $2500 \mathrm{~kg} \mathrm{ha}^{-1}$ & $5000 \mathrm{~kg} \mathrm{ha}^{-1}$ \\
\hline Bishoftu Netch & $21.15^{\mathrm{e}}$ & $22.72^{\mathrm{d}}$ & $28.15^{\mathrm{b}}$ \\
Local & $21.55^{\mathrm{d}}$ & $24.22^{\mathrm{c}}$ & $31.25^{\mathrm{a}}$ \\
Tsedey & $17.81^{\mathrm{f}}$ & $24.05^{\mathrm{c}}$ & $25.00^{\mathrm{c}}$ \\
\hline LSD (5\%) & 1.224 & & \\
CV $(\%)$ & 5.9 & & \\
\hline
\end{tabular}

* Means followed by the same letter within a column are not significantly different at $5 \%$ level of significance, $\mathrm{LSD}=$ Least significant differences; $\mathrm{CV}=$ coefficient of variation .

\subsection{Number of Leaves per Plant}

Number of leaves per plant is affected by varieties and vermicompost significantly $(\mathrm{P}<0.001)$. However, the interaction of the two factors failed to influence the number of leaves per plant. Bishoftu Nech produced significantly a greater number of leaves per plant than the other cultivars. The main effect of garlic varieties and vermicompost showed higher number of leaves (14.86) were recorded from plants supplied with rate of $5000 \mathrm{~kg}$ ha $^{-1}$ vermicompost (Table 4). The availability of higher quantity of nutrients, improvement in the physical properties of soil and increased activity of microbes with higher levels of organics due to vermicompost might have helped in increasing number of leaves.

Table 4. Main effects of garlic varieties and vermicompost on leaf number

\begin{tabular}{|c|c|}
\hline Treatments & Leaf number per plant \\
\hline \multicolumn{2}{|l|}{ Varieties } \\
\hline Local & $10.56^{\mathrm{b}}$ \\
\hline Tsedey & $10.31^{\mathrm{b}}$ \\
\hline Bishoftu Netch & $11.10^{\mathrm{a}}$ \\
\hline $\operatorname{LSD}(5 \%)$ & 0.305 \\
\hline \multicolumn{2}{|l|}{ Rate of vermicompost } \\
\hline No fertilizer (control) & $10.01^{\mathrm{c}}$ \\
\hline $2500 \mathrm{~kg} \mathrm{ha}^{-1}$ vermicompost & $10.12^{\mathrm{b}}$ \\
\hline $5000 \mathrm{~kg} \mathrm{ha}^{-1}$ vermicompost & $14.86^{\mathrm{a}}$ \\
\hline $\operatorname{LSD}(5 \%)$ & 0.46 \\
\hline $\mathrm{CV}(\%)$ & 5.1 \\
\hline
\end{tabular}

*Means followed by the same letter within a column are not significantly different at $5 \%$ level of significance, $\mathrm{LSD}=$ Least significant differences; $\mathrm{CV}=$ coefficient of variation.

\subsection{Leaf Area Index}

Leaf area index is influenced by varieties, vermicompost and their interaction significantly at $5 \%$ level of significance. Highest (0.55) and lowest (0.17) leaf area index recorded was in local garlic cultivar fertilized with $5000 \mathrm{~kg} \mathrm{ha}^{-1}$ vermicompost and no vermicompost, respectively (Table 5). Alemu (2016) reported that application of vermicompost supplement at a rate of $5000 \mathrm{~kg} \mathrm{ha}^{-1}$ increased leaf area index of garlic by $15.15 \%$ over the control. The increment in leaf area index may be due to enhanced vegetative growth and bulb filling by nitrogen (Tadila, 2011) and influence on photosynthetic productivity by phosphorus.

Table 5. Interaction effects of garlic varieties and vermicompost on leaf area index

\begin{tabular}{llll}
\hline & \multicolumn{3}{c}{ Rate of vermicompost } \\
\cline { 2 - 4 } Varieties & No fertilizer (control) & $2500 \mathrm{~kg} \mathrm{ha}^{-1}$ & $5000 \mathrm{~kg} \mathrm{ha}^{-1}$ \\
\hline Bishoftu Netch & $0.18^{\mathrm{f}}$ & $0.41^{\mathrm{d}}$ & $0.46^{\mathrm{c}}$ \\
Local & $0.17^{\mathrm{g}}$ & $0.34^{\mathrm{e}}$ & $0.55^{\mathrm{a}}$ \\
Tsedey & $0.19^{\mathrm{f}}$ & $0.39^{\mathrm{d}}$ & $0.50^{\mathrm{b}}$ \\
\hline LSD (5\%) & 0.029 & & \\
CV $(\%)$ & 6.0 & &
\end{tabular}

* Means followed by the same letter within a column are not significantly different at $5 \%$ level of significance, $\mathrm{LSD}=$ Least significant differences; $\mathrm{CV}=$ coefficient of variation .

\subsection{Mean Bulb Weight}

Mean bulb weight was influenced by the main effects of varieties, vermicompost and interaction of the two factors at $1 \%$ level of significance. Highest mean bulb weight was recorded in Bishoftu Nech variety with application of $5000 \mathrm{~kg} \mathrm{ha}^{-1}$ vermicompost while minimum mean bulb weight $(23.50 \mathrm{~g})$ was recorded in Tsedey at the control treatment. Unfertilized plots of all varieties produced lower mean bulb weight (Table 6). 
Table 6. Interaction effects of garlic varieties and vermicompost fertilizer on mean bulb weight (g)

\begin{tabular}{llcc}
\hline \multirow{2}{*}{ Varieties } & \multicolumn{3}{c}{ Rate of vermicompost } \\
\cline { 2 - 4 } & $\begin{array}{l}\text { No fertilizer } \\
\text { (control) }\end{array}$ & $2500 \mathrm{~kg} \mathrm{ha}^{-1}$ & $5000 \mathrm{~kg} \mathrm{ha}^{-1}$ \\
\hline Bishoftu Netch & $29.55^{\mathrm{d}}$ & $31.59^{\mathrm{c}}$ & $37.85^{\mathrm{a}}$ \\
Local & $25.52^{\mathrm{e}}$ & $32.00^{\mathrm{c}}$ & $34.85^{\mathrm{b}}$ \\
Tsedey & $23.50^{\mathrm{f}}$ & $31.80^{\mathrm{c}}$ & $34.68^{\mathrm{b}}$ \\
\hline LSD $(5 \%)$ & 1.267 & & \\
CV $(\%)$ & 6.6 & & \\
\hline
\end{tabular}

*Means followed by the same letter within a column are not significantly different at $5 \%$ level of significance, $\mathrm{LSD}=$ Least significant differences; $\mathrm{CV}=$ coefficient of variation .

\subsection{Mean Clove Weight}

The main effects of variety, vermicompost as well as their interaction showed significance $(\mathrm{P}<0.001)$ difference on mean clove weight. As shown in Table 9 below, Bishoftu Nech fertilized with $5000 \mathrm{~kg} \mathrm{ha}^{-1}$ vermicompost produced the highest mean clove weight $(5.31 \mathrm{~g})$ which was $155 \%$ more than the least mean clove weight recorded in the local cultivar from non-fertilized plot. Application of $2500 \mathrm{~kg} \mathrm{ha}^{-1}$ vermicompost in Bishoftu Nech also increased mean clove weight by $95.9 \%$ and 94\%, respectively; compared to non-fertilized (control) Bishoftu Nech plants.

Table 7. Interaction effects of garlic varieties and vermicompost on mean clove weight $(\mathrm{g})$

\begin{tabular}{llll}
\hline & \multicolumn{3}{c}{ Rate of vermicompost } \\
\cline { 2 - 4 } Varieties & No fertilizer (control) & $2500 \mathrm{~kg} \mathrm{ha}^{-1}$ & $5000 \mathrm{~kg} \mathrm{ha}^{-1}$ \\
\hline Bishoftu Netch & $2.65^{\mathrm{e}}$ & $5.10^{\mathrm{b}}$ & $5.65^{\mathrm{a}}$ \\
Local & $2.28^{\mathrm{f}}$ & $4.03^{\mathrm{c}}$ & $4.95^{\mathrm{bc}}$ \\
Tsedey & $2.14^{\mathrm{f}}$ & $3.45^{\mathrm{d}}$ & $3.13^{\mathrm{d}}$ \\
\hline LSD (5\%) & 0.381 & & \\
CV (\%) & 7.4 & &
\end{tabular}

*Means followed by the same letter within a column are not significantly different at $5 \%$ level of significance, $\mathrm{LSD}=$ Least significant differences; $\mathrm{CV}=$ coefficient of variation

\subsection{Total Fresh Biomass Yield}

Total fresh biomass yield was significantly influenced by effect of varieties, vermicompost and their interaction. Table 10 below showed that uppermost fresh biomass yield (47.82 g) was recorded on Bishoftu Nech with application of $5000 \mathrm{~kg} \mathrm{ha} \mathrm{k}^{-1}$ vermicompost while minimum record was observed on the local variety in the unfertilized plots. Tseday showed the lowest fresh biomass yield $(26.55 \mathrm{~g})$ than the other cultivars when unfertilized. In all cultivars, the unfertilized plots produced lower mean fresh bulb yield than fertilized plots. The increment in fresh biomass yield due to vermicompost is because it contains several plant growth promoters, enzymes, beneficial bacteria and mycorrhyzae (Gupta, 2005).

Table 8. Interaction effects of garlic varieties and vermicompost on mean total fresh biomass yield ( $\mathrm{g} / \mathrm{plant})$

\begin{tabular}{llll}
\hline \multirow{2}{*}{ Varieties } & \multicolumn{3}{c}{ Rate of vermicompost } \\
\cline { 2 - 4 } & $\begin{array}{c}\text { No fertilizer } \\
\text { (control) }\end{array}$ & $2500 \mathrm{~kg} \mathrm{ha}^{-1}$ & $5000 \mathrm{~kg} \mathrm{ha}^{-1}$ \\
\hline Bishoftu Netch & $39.74^{\mathrm{b}}$ & $42.12^{\mathrm{b}}$ & $47.82^{\mathrm{a}}$ \\
Local & $33.00^{\mathrm{a}}$ & $40.27^{\mathrm{b}}$ & $46.65^{\mathrm{a}}$ \\
Tsedey & $29.01^{\mathrm{c}}$ & $39.98^{\mathrm{b}}$ & $41.13^{\mathrm{b}}$ \\
\hline LSD (5\%) & 4.132 & & \\
CV $(\%)$ & 9.5 & & \\
\hline
\end{tabular}

*Means followed by the same letter within a column are not significantly different at $5 \%$ level of significance, $\mathrm{LSD}=$ Least significant differences; $\mathrm{CV}=$ coefficient of variation

\subsection{Marketable Bulb Yield}

Variety and vermicompost as well as their interaction significantly $(\mathrm{P}<0.001)$ influenced marketable bulb yield. Significantly the highest marketable yield ( 8.10 ton $\mathrm{ha}^{-1}$ ) was recorded in Bishoftu Nech with application of 5000 $\mathrm{kg} \mathrm{ha}^{-1}$ vermicompost (Table 9). This marketable yield was $24 \%$ and $56 \%$ higher than Tsedey and the local cultivar at the same rate of fertilizer application, respectively. The increment in marketable bulb yield due to the application of vermicompost fertilizer could be due to the increment in vegetative growth and increased production of assimilate which is associated with increment in leaf area index and mean bulb. Alemu (2016) reported that higher 
marketable yield was recorded at the application of vermicompost $5000 \mathrm{~kg} \mathrm{ha}^{-1}$.

Table 9. Interaction effects of garlic varieties and vermicompost on marketable bulb yield (ton ha-1)

\begin{tabular}{llll}
\hline & \multicolumn{3}{c}{ Rate of vermicompost } \\
\cline { 2 - 4 } Varieties & No fertilizer (control) & $2500 \mathrm{~kg} \mathrm{ha}^{-1}$ & $5000 \mathrm{~kg} \mathrm{ha}^{-1}$ \\
\hline Bishoftu Nech & $4.79^{\mathrm{e}}$ & $7.08^{\mathrm{b}}$ & $8.10^{\mathrm{a}}$ \\
Local & $3.35^{\mathrm{g}}$ & $5.43^{\mathrm{d}}$ & $5.66^{\mathrm{d}}$ \\
Tsedey & $3.89^{\mathrm{f}}$ & $6.15^{\mathrm{c}}$ & $6.74^{\mathrm{b}}$ \\
\hline LSD $(5 \%)$ & 0.462 & & \\
CV $(\%)$ & 4.6 & & \\
\hline
\end{tabular}

*Means followed by the same letter within a column are not significantly different at $5 \%$ level of significance,

$\mathrm{LSD}=$ Least significant differences; $\mathrm{CV}=$ coefficient of variation

\subsection{Total Bulb Yield}

The main effects of variety and vermicompost and their interaction appeared to be significant $(\mathrm{P}<0.001)$. As designated in Table 10 below, Bishoftu Nech fertilized with $5000 \mathrm{~kg} \mathrm{ha}^{-1}$ vermicompost produced the highest total bulb yield ( 8.50 ton $\mathrm{ha}^{-1}$ ) which was about $31 \%$ and $54 \%$ higher than in Tsedey and local cultivar with the same rate of application, respectively. The lowest bulb yield (4.83 ton ha-1) was found from Tseday with no fertilizer application.

Table 10. Interaction effects of garlic varieties and vermicompost on total bulb yield (ton ha $\left.{ }^{-1}\right)$

\begin{tabular}{llll}
\hline \multirow{3}{*}{ Varieties } & \multicolumn{3}{c}{ Rate of vermicompost } \\
\cline { 2 - 4 } & No fertilizer (control) & $2500 \mathrm{~kg} \mathrm{ha}^{-1}$ & $5000 \mathrm{~kg} \mathrm{ha}^{-1}$ \\
\hline Bishoftu Nech & $5.57^{\mathrm{cd}}$ & $6.96^{\mathrm{b}}$ & $8.5^{\mathrm{a}}$ \\
Local & $5.12^{\mathrm{e}}$ & $5.32^{\mathrm{de}}$ & $5.50^{\mathrm{d}}$ \\
Tsedey & $4.83^{\mathrm{f}}$ & $5.69^{\mathrm{c}}$ & $6.48^{\mathrm{b}}$ \\
\hline LSD $(5 \%)$ & 0.482 & & \\
CV $(\%)$ & 6.24 & & \\
\hline
\end{tabular}

*Means followed by the same letter within a column are not significantly different at $5 \%$ level of significance, VC

$=$ vermicompost

\section{Conclusions}

Results of the experiment showed the longest days to bulb maturity 146.67 and the shortest days to maturity 128 were recorded in Tsedey variety that received $2500 \mathrm{~kg} \mathrm{ha}^{-1}$ vermicompost and control treatment, respectively. Similarly, the highest plant height $(31.25 \mathrm{~cm})$ was attained by the local cultivar with application of $5000 \mathrm{~kg} \mathrm{ha}^{-1}$ vermicompost and the minimum $(17.81 \mathrm{~cm})$ was recorded in Tsedey that received no fertilizer. Moreover, the highest (14.86) leaf number was recorded in local cultivar with the application of $5000 \mathrm{~kg} \mathrm{ha}^{-1}$ vermicompost while the minimum (10.31 leaf number was observed on Tsedey that relieved no fertilizer.

Significantly the highest mean clove weight $(5.65 \mathrm{~g})$, total fresh biomass yield (47.82 g/plant), marketable bulb yield ( 8.10 ton $\mathrm{ha}^{-1}$ ) and total bulb yield $\left(8.5\right.$ ton $\left.^{-1}\right)$, highest mean bulb weight $(37.85 \mathrm{~g})$ were recorded on Bishoftu Nech variety that were fertilized with $5000 \mathrm{~kg} \mathrm{ha}^{-1}$ vermicompost. In addition, the highest harvest index was recorded in local cultivar that received application of $5000 \mathrm{~kg} \mathrm{ha}^{-1}$. Moreover, the interaction effect of varieties and vermicompost highly significantly $(\mathrm{P}<0.001)$ affected days to bulb maturity, plant height, leaf area index, mean bulb weight, mean clove weight, total fresh biomass yield, marketable number of bulbs, marketable bulb yield and total bulb yield. In conclusion, the result of the present study indicated that the highest total bulb yield was recorded from Bishoftu Nech by applying of $5000 \mathrm{~kg} \mathrm{ha}^{-1}$ vermicompost.

\section{Reference}

Ahmad N., Rashid M. and Vaes A.G. (1996). Fertilizers and their uses in Pakistan. NFDC. Pp. 142-175.

Alemu Degwale. (2016). Effect of Integrated Application of Vermicompost and Inorganic NP Fertilizers on Growth, Yield and Quality of Garlic (Allium sativum L.) in Enebse Sar Midir District, Northwestern Ethiopia. Journal of Biology, Agriculture and Healthcare, 6:1-19.

Arancon N.Q., Edwards C.A., Bierman P., Welch C. and Metzger J.D.(2004). Influences of vermicomposts on field strawberries-1: Effects on growth and yields. Bioresource Technology, 93: 145-153.

Argüello J.A., Ledesma A., Núñez S.B., Rodríguez C.H. and Díaz Goldfarb M.D.C. (2006). Vermicompost Effects on Bulbing Dynamics Nonstructural Carbohydrate Content, Yield, and Quality of 'Rosado Paraguayo' Garlic Bulbs. HortScience , 41 (3): 589-592.

Atiyeh R.M., Lee Edward C.A., Arancon N.Q. and Metzger J.D. (2002). The influence of humic acids derived from earthworm-processed organic wastes on plant growth. Bioresource Technology, 84: 7-14.

Central Statistical Agency (CSA). (2014/2015). Agricultural Sample Survey 2012/2013. Report on Area and 
Production of Crops (Private Peasant Holdings, Meher season). Democratic Republic of Ethiopia, Central Statistical Authority, Addis Ababa. May 2013. Statistical bulletin, 532, Volume I. DOI: http://www.csa.gov.et/ (Accessed 06 August 2016)

CIMMYT. (1988). From agronomic data to farmer recommendation. An economic training manual. Completely revised edition. D.F. Mexico. Pp. 9-12.

Etoh, T. and P.W. Simon. (2002). Diversity, fertility and seed production of garlic. pp. 101-117. In: Rabinowitch, H.D. and L.Currah (Eds.). Allium Crop Science: Recent Advances. CAB International, Wallingford, UK.

Fikreyohannes Gedamu. (2005). Effects of clove size and plant density on the bulbYield and yield components of garlic (Allium sativum L.) in Awabel woreda, East Gojjam zone. MSc Thesis, Haramaya Univeristy, Haramaya, Ethiopia.

Gezahegn G., Andergachew G., Kelsa K. (2014). Combined effects of inorganic (NP) and farm yard manure (FYM) fertilizers on root yield and above ground biomass of sweet potato (Ipomoea batatas L.) at Delbo watershed Wolaita Zone, Southern Ethiopia. Journal Science Research and Reviews, 3(2):28 - 33

Gupta, P. K. (2005). Vermicomposting for Sustainable Agriculture, AGROBIOS (India), Jodhapur, pp. 210.

Hesse, P.R. (1971). A text book of soil chemical analysis. John Murray, London. http://extension.usu.edu/.

Kale R.D., Mallesh B.C., Bano K., Bagyaraj D.J. (1992). Influence of vermicompost application on the available macronutrients and selected microbial pupulations in the paddy field. Soil Biology Biochemstry, 24:1317-20.

Khaliq T., Mahmood T., Kamal J. and Masood A. (2004). Effectiveness of farmyard manure, poultry manure and nitrogen for corn (Zea mays L.) productivity. International Journal of Agriculture and Biology, 2: $260-263$.

Khaliq T., Mahmood T., Kamal J. and Masood A. (2004). Effectiveness of farmyard manure, poultry manure and nitrogen for corn (Zea mays L.) productivity. International Journal of Agriculture and Biology, 2: $260-263$.

Nagavallemma K.P., Wani S.P., Lacroix S., Padmaja V.V., Vineela C., BabuRao M., Sahrawat K.L. (2004). Vermicomposting: Recycling wastes into valuable organic fertilizer. Global Theme on Agrecosystems Report no. 8. Patancheru 502-324, Andhra Pradesh, India: International Crops Research Institute for the Semi-Arid Tropics. $20 \mathrm{pp}$

Nelson, N.A, and Sommer. (1982). Photometric adaptation of Somogy method for the determination of glucose. Journal of Biological Chemistry, 153: 375-380.

Olsen, S.R., C.V. Cole, F.S. Watanabe and L. A. Dean. (1954). Estimation of available phosphorus in soils by extraction with sodium bicarbonate. U.S. Dep. Agric. Circ.939, USA.

Palm, C.A., R.J.K. Myers and S.M. Nandwa. (1997). Combined use of organic and inorganic nutrient sources for soil fertility maintenance and replenishment. pp. 193-217.

Surindra, S. (2009). Impact of vermicompost and composted farmyard manure on growth and yield of garlic (Allium stivum L.) field crop. International Journal of Plant Production 3 (1).

Tadila Getaneh. (2011). Effect of manure and nitrogen rates on yield and yield components of garlic (Allium sativum L.) at Haramaya, Easter Ethiopia. MSc Thesis, Haramaya University, Haramaya, Ethiopia.

Yesigat, M. (2008). Yield and Growth of Garlic (Allium sativum L.) Varieties as Affected by Plant Density at Wadla, North Ethiopia. M.Sc Thesis, Univerity of Hawassa, Ethiopia, 50-74. 